\title{
AYLA SAROZ \\ UNREWARDED DONORS: THE SEARCH FOR VICTIMS IN THE WAKE OF KAPA
}

Submitted for the LLB (Honours) Degree

Faculty of Law

Victoria University of Wellington

2013 


\section{Contents}

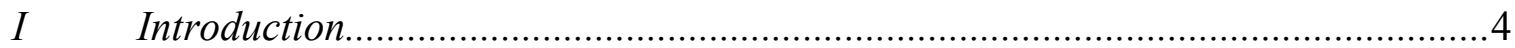

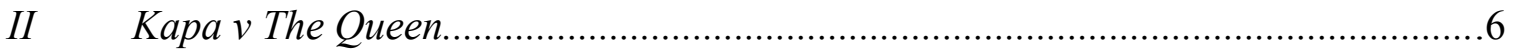

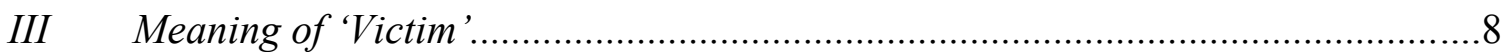

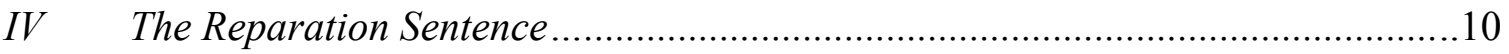

A Historical Development of Reparation.........................................14

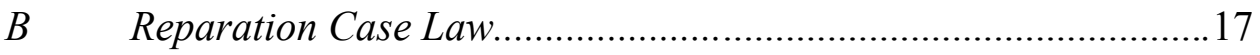

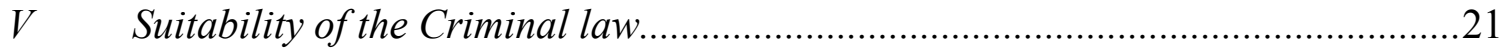

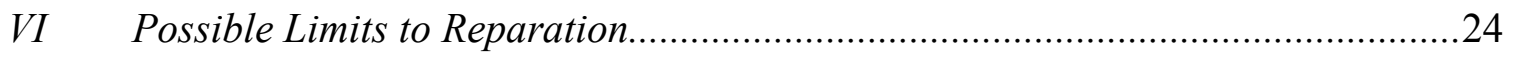

A Changing the Definition of 'Victim' '.............................................25

B Removing the Requirement of 'Victim' .......................................27

VII Conclusion 


\begin{abstract}
This paper provides a critical analysis of the sentence of reparation in New Zealand, as set out by s 32 of the Sentencing Act 2002. The scope of the sentence is examined with particular regard to the recent Supreme Court decision, which limited reparation so that only victims of offences can benefit from the sentence. The definition of "victim", as determined by the Sentencing Act, is confined to direct victims of criminal offending. Thus, any indirect victim suffering harm or loss from criminal offending cannot benefit from reparation. This paper questions whether that limitation gives reparation an appropriate scope, or whether some extension should be made so that the sentence is not restricted in its application to only benefit direct victims. In so doing, this paper argues that the criminal law is the suitable domain to address such issues of compensation and therefore, an extension of the reparation sentence is required. Alternative ways of limiting reparation to address this compensation issue are outlined. Ultimately it is proposed that an additional provision should be included within the definition of "victim", for the purpose of s 32 , so that indirect victims can also benefit from a sentence of reparation.
\end{abstract}

\title{
Key words
}

sentencing; reparation; victim; compensation 


\section{Introduction}

This paper takes the form of an extended case note based on the recent decision of Kapa $v$ $R$ (Kapa). ${ }^{1}$ It will focus on the Supreme Court judgment, particularly the majority's approach, which limited the sentence of reparation to direct victims of offences. The limitation resulted in two members of the public who had contributed money towards a reward for the recovery of stolen property being unable to benefit from a reparation sentence.

The main considerations of this paper are how appropriate the 'victim' limitation is on the reparation sentence, and whether an extension of the provision is called for. An extension could make the sentence available to those outside the definition of 'victim' who have nonetheless been affected by criminal behaviour and in some way suffered loss. The issues to examine include whether the criminal law, through reparation, is suited to addressing questions of compensation for indirect victims, and what the possibilities are if the law is extended to do so. These will be explored with a view to making an informed determination as to the best way to develop reparation law in New Zealand.

It will be shown that compensation by way of a reparation sentence should not be limited to those deemed to be direct 'victims' of criminal offending; the sentence ought to compensate even indirect victims who suffer some loss or harm as a result of the criminal behaviour. An extension of reparation beyond direct victims is easily reasoned by an investigation into the relevant Sentencing Act 2002 provisions $^{2}$ and by looking to the rationales and historical background that underpin the sentence. ${ }^{3}$ The suggested development can also be justified by the importance of rectifying any imbalance created by criminal offending; that is, making right any loss or harm resulting from any criminal

\footnotetext{
${ }^{1}$ Kapa $v$ R [2012] NZSC 1.

${ }^{2}$ Sentencing Act 2002, s 32.

${ }^{3}$ See Ministry of Justice Sentencing Policy and Guidance - A Discussion Paper (November 1997, Wellington) at 3.5.3.
} 
conduct so that those suffering loss are reverted back to their original position. ${ }^{4}$ Reparation serves to restore equilibrium, because the burden of any loss or harm suffered is transferred to the offender through the implementation of the sentence as part of the convicted offender's punishment. ${ }^{5}$ Kapa provides a clear example of where the reparation sentence currently falls short in upholding these ideals.

The prospect of extending reparation beyond direct victims does give rise to two major concerns. The first is whether the criminal law is the best medium to address the issue of compensation for indirect victims of criminal offending. There is scope to reason that such questions of compensation are better addressed by other legal mechanisms, or left entirely to civil law processes. This would require the individuals concerned to pursue these matters as a separate civil action, since compensation is unavailable within the criminal justice process. It is important to acknowledge the existence of civil compensation mechanisms as alternative means of redress and to understand how they compare to possible avenues of compensation within the criminal law. Although civil law mechanisms may be available in certain circumstances, it will be shown that reparation through the criminal law is the more suitable means by which to compensate those who are not 'victims' but who have nonetheless been harmed or suffered loss from criminal offending.

The second concern is the question of where the appropriate limit to reparation lies. If the scope of the sentence is extended, then some limitation is required so that its application does not become open-ended. Where the threshold for reparation ought to lie will be examined. An analysis will be made both of the alternative ways to limit reparation, since the current definition of 'victim' is deemed to be inappropriate, and of the implication of these alternatives should such a change be invoked.

\footnotetext{
${ }^{4}$ See S Easton and C Piper Sentencing and Punishment: The Quest for Justice (2 ${ }^{\text {nd }}$ ed, Oxford University Press, Oxford 2008) at ch 6.

${ }^{5}$ See generally A von Hirsch Censure and Sanctions (Oxford University Press, New York, 1993).
} 
It is important to note that if reparation were extended, the extension would only affect a relatively small number of cases where there is no direct victim, but some 'indirect victim' has nonetheless suffered an identifiable loss and ought to be compensated. Alternative mechanisms may also be available in some cases to address this sort of issue. For example, where a convicted criminal should receive some pecuniary punishment a fine may be imposed ${ }^{6}$ or an individual may be subjected to a profit forfeiture order for property unlawfully acquired through criminal activity, irrespective of whether there is a victim or even any criminal conviction. ${ }^{7}$ Such mechanisms ultimately focus on punishment, rather than compensation. This paper, however, will focus on addressing the main issue that was considered by the Supreme Court in Kapa, and reflect on what should happen in any cases where some compensation is sought but where there is a barrier to bringing any alternative charge.

\section{Kapa v The Queen}

The Supreme Court in Kapa considered whether the sentence of reparation was limited to victims of offences. The issue arose in terms of whether reward donors were persons for whose benefit a sentence of reparation could be made. ${ }^{8}$

In 2007, two men burgled the National Army Museum and stole 96 gallantry medals. The theft caused a stir throughout the country and the Commissioner of Police offered a reward for information or evidence that would lead to the closure of the case and recovery of the medals. Two members of the public, Lord Ashcroft and Tom Sturgess, offered to provide funding for any reward made.

Mr Comesky, an Auckland lawyer, offered the return of the medals in exchange for the reward money and the Commissioner agreed. The names of Comesky's clients were not

\footnotetext{
${ }^{6}$ See Sentencing Act, s 39; and G Hall Hall's Sentencing (Butterworths, Wellington, 1993) at [SA39.3].

${ }^{7}$ See Criminal Proceeds (Recovery) Act 2009, s 55.

${ }^{8}$ At [7].
} 
disclosed. This development led to the return of the medals and a reward payment of more than $\$ 200,000$ being made.

James Kapa was one of the two men later arrested and charged with burglary in relation to the stolen medals as a result of further police investigation. He pleaded guilty to the charge. Prior to his arrest, Kapa was Comesky's client and had received $\$ 100,000$ of the reward money. Kapa accepted that he and his accomplice had used Comesky "to broker a deal to return the medals for a sum of the reward money". 9

In the District Court, Kapa was sentenced to imprisonment and a reparation sentence of $\$ 100,000$ was imposed. ${ }^{10}$ His appeal against the reparation sentence was rejected in the Court of Appeal. ${ }^{11}$ Kapa then appealed to the Supreme Court, where the Court analysed the question of whether the imposition of reparation complied with the requirements of the Sentencing Act (SA), s $32 .^{12}$

The issue that arose is whether that "person" in s 32(1) who suffers loss, damage or harm is limited to the victim of the crime, or whether any person who has suffered loss, damage or harm from the offending can benefit from a reparation sentence. ${ }^{13}$ The Crown's argument that any "person" could potentially be the recipient of a sentence of reparation under s 32 was rejected. ${ }^{14}$ The majority of the Supreme Court held that only victims can benefit from reparation, so Ashcroft and Sturgess were not eligible to have reparation invoked in their favour. ${ }^{15}$

The judgment brings to light the issues created by this limit on the reparation sentence. Only victims can be the beneficiaries of a sentence of reparation under s 32 . Section 4 of SA provides that, for the purposes of the Act, a victim is "a person against whom an

\footnotetext{
${ }^{9}$ At [4].

${ }^{10} R v$ Kapa DC Auckland CRI-2008-083-2487, 26 August 2010 at [27].

${ }^{11}$ Kapa $v R$ [2011] NZCA 504 at [40].

${ }^{12}$ At [6].

${ }^{13}$ At [7].

${ }^{14}$ At [11].

${ }^{15}$ At [11] and [36].
} 
offence is committed, or a person who, through or by means of an offence, suffers injury, or loss or damage to property". ${ }^{16}$ Those outside this definition of 'victim' must look to other areas of the law if they are to be compensated for their loss. Without a separate civil action being taken by an individual or group, the loss resulting from the criminal conduct remains a burden of the person harmed by the offending. Ideally, reparation should fulfil its role as a loss-shifting mechanism, so that the loss resulting from the crime in question is transferred to the offender. ${ }^{17}$ This will not always be possible if reparation remains narrow in scope, shifting the burden of the loss only where a direct victim can be identified according to the restrictive definition.

In the light of the result in Kapa, this paper proposes an extension of the criminal law so that any loss suffered by indirect victims through or by means of criminal offending can be appropriately recognised and mitigated by the reparation sentence.

\section{Meaning of 'Victim'}

It is crucial first to understand who is considered to be a victim for reparation purposes.

Under s 4 of the Act: ${ }^{18}$

\section{Victim-}

[(a) means-

(i) a person against whom an offence is committed by another person; and

(ii) a person who, through, or by means of, an offence committed by another person, suffers physical injury, or loss of, or damage to, property; and

(iii) a parent or legal guardian of a child, or of a young person, who falls within subparagraph (i) or subparagraph (ii), unless that parent or guardian is charged with

\footnotetext{
${ }^{16}$ Sentencing Act, s4, definition of "victim", paras (a)(i) and (a)(ii).

${ }^{17}$ New Zealand Law Commission Compensating Crime Victims (NZLC R121, 2010) at 2.11; see also N Walker Sentencing: Theory, Law and Practice (London, Butterworths, 1985) at 8.36; and A Ashworth Sentencing and Criminal Justice ( $3^{\text {rd }}$ ed, Butterworths, London, 2000) at 75-77.

${ }^{18}$ Sentencing Act, s 4.
} 
the commission of, or convicted or found guilty of, or pleads guilty to, the offence concerned; and

(iv) a member of the immediate family of a person who, as a result of an offence committed by another person, dies or is incapable, unless that member is charged with the commission of, or convicted or found guilty of, or pleads guilty to, the offence concerned; ]

This definition is similar to others found in recently enacted criminal legislation. For example, it does not greatly differ from that in the Victims' Rights Act 2002 (VRA). ${ }^{19}$ Other statutes that define 'victim' in substantially the same way include the Parole Act 2002 (PA), the Prisoners' and Victims' Claims Act 2005 (PVCA) and the Criminal Procedure Act 2011 (CPA). These statutes all, to some extent, recognise the interests of victims of crime.

The VRA includes within 'victim' those who are directly affected by the offence, the parent or guardian of the person directly affected if that person is under 17 years old, and finally, it includes a person's immediate family where the person directly affected has died or is otherwise incapable. ${ }^{20}$ Additionally, the VRA allows a wider interpretation of 'victim' for the purpose of certain provisions. For example, a person suffering emotional harm is a victim for the purposes of ss 7-8, dealing with victims' treatment and access to services. Similarly, a person can be treated as a victim for victim impact statement purposes if the prosecutor considers it appropriate to do so, even if that person is not the victim, offender nor the accused. ${ }^{21}$ Only two requirements must be satisfied in that case: the person must be disadvantaged by an offence and he or she must be able to provide information about the effects of the offence. ${ }^{22}$ The PVCA has substantially the same definition of 'victim' as the SA, ${ }^{23}$ while the CPA takes the VRA s 4 definition. ${ }^{24}$

\footnotetext{
${ }^{19}$ Victims' Rights Act 2002, s 4; see also B Robertson Adams on Criminal Law - Sentencing (online looseleaf ed, Brookers) at SA 4.23.01.

${ }^{20}$ Victims' Rights Act, s 4.

${ }^{21}$ Victims' Rights Act, s 20.

${ }^{22}$ Victims' Rights Act, s 20.

${ }^{23}$ Prisoners' and Victims' Claims Act 2005, s 8.

${ }^{24}$ Criminal Procedure Act 2011, s 5.
} 
The Parole Act defines 'victim' more narrowly than the VRA and SA, limiting the term to those who are on the victim notification register. ${ }^{25}$ However, the Act also includes provisions that confer rights to those considered as victims in a much wider sense. ${ }^{26}$ These wider provisions include the guiding principles of the Act, where the VRA s 4 definition of victim is adopted. ${ }^{27}$

Although there is little difference in the definition of 'victim' across these statutes, in certain circumstances the term is given wider scope. These victims' provisions identify those who ought to be granted rights by virtue of having their interests violated in some way by criminal offending. The legislation also serves as a framework to determine the responsibilities of either the state or a particular agency, which is then charged with the protection of those rights. Despite this codification of victims' rights, much of the legislation is legally unenforceable, ${ }^{28}$ and provides more of a normative framework as to how victims ought to be treated in the course of criminal justice proceedings. The provisions are nonetheless useful to clarify who may be seen as a victim in more general terms. Although the definition of 'victim' can be extended or adapted in particular situations, such provision is not presently made for reparation in $\mathrm{s} 32$. Having an extended definition of 'victim' for the purpose of a reparation sentence would not be unprecedented by virtue of these adapted or extended definitions already enacted for other purposes.

\section{The Reparation Sentence}

The SA establishes the sentence of reparation in New Zealand. Reparation is permitted in three circumstances by s $32(1)$, which reads as follows: ${ }^{29}$

\footnotetext{
${ }^{25}$ Parole Act 2002, s 4.

${ }^{26}$ See Parole Act, ss 43-45, 47, 49-50B.

${ }^{27}$ Parole Act, s 7.

${ }^{28}$ See Victims' Rights Act, s 10.

${ }^{29}$ Sentencing Act, s 32.
} 
32 Sentence of reparation

(1) A court may impose a sentence of reparation if an offender has, through or by means of an offence of which the offender is convicted, caused a person to suffer -

(a) Loss of or damage to property; or

(b) Emotional harm; or

(c) Loss or damage consequential on any emotional or physical harm or loss of, or damage to, property.

The majority in Kapa held that s 32 is connected in such a way to the s 4 SA definition of victim so that only victims are able to be beneficiaries of a reparation sentence. ${ }^{30}$ This significantly limits the sentence to the extent that even those who have suffered loss, the reward donors in Kapa, are unable to be compensated for their losses by means of reparation. $^{31}$

Having already identified where the current provisions may be falling short of providing compensation in some circumstances, it is best now to look at reparation in terms of where there may be scope to extend its application to better address situations where compensation should be made available. A proper analysis can be made through the rationales of the reparation sentence. These rationales can be examined in the light of the historical enactment and judicial interpretation of reparation, before looking at how the current sentence is interpreted in comparison.

Sentencing can be analysed with regard to the criminal justice process as a whole. As a starting point, the criminalisation of behaviour ensures that offenders suffer public censure for their wrongful action through conviction. ${ }^{32}$ When conduct is determined to be criminal, Parliament is authorising the imposition of punishment to deprive the offender of some right. ${ }^{33}$ When a sentence is being considered, the offender has already been

\footnotetext{
${ }^{30}$ At [11].

${ }^{31}$ See Kapa $v$ R, above $\mathrm{n} 1$ at [36].

${ }^{32}$ RA Duff Answering for Crime: Responsibility and Liability in the Criminal Law (Hart, Oxford, 2007) at 123.

33 A Ashworth Principles of Criminal Law (4 $4^{\text {th }}$ ed, Oxford University Press, 2003) at 19; see also AP Simester and WJ Brookbanks Principles of Criminal Law (Brookers, Wellington, 2012) at ch 1.2.2.
} 
prosecuted for and convicted of a crime. It is then appropriate to make right any harm caused by the offender by invoking a punishment to express "moral condemnation" through the judicial power to sentence. ${ }^{34}$ A sentence might strip the offender of gain made through the criminal activity, appease any violations of interests, or otherwise punish the wrongdoer. ${ }^{35}$

Any punishment imposed must be justified. ${ }^{36}$ Penological principles provide "the justifications of punishment". 37 Widespread recognition of reparation as part of punishment developed from the 1980s. During that time, it was noted in Britain "that room should be found within the criminal justice process for some kind of reparation or reconciliation". 38 This development in sentencing was acknowledged as a "shift from principles of punishment, deterrence and rehabilitation to the principle of undoing the harm done by means such as restitution, compensation and community service." ${ }^{39}$ The reparation sentence with its restitutionary focus is tied to this ideology. ${ }^{40}$

The SA establishes the purposes of sentencing in New Zealand. ${ }^{41}$

7 Purposes of sentencing or otherwise dealing with offenders

(1) The purposes for which a court may sentence or otherwise deal with an offender are-

(a) to hold the offender accountable for harm done to the victim and the community by the offending; or

\footnotetext{
$\overline{{ }^{34} \text { Easton and Piper, above n 4, at 4; see also Joel Feinberg 'The Expressive Function of Punishment' in A }}$ Duff and D Garland (eds) A Reader on Punishment (Oxford University Press, Oxford, 1994) at 71.

${ }^{35}$ For further discussion see DA Thomas Sentencing: The Basic Principles [1967] Crim LR 455 and 503 ; Clarkson and Keating Criminal Law $\left(6^{\text {th }} \mathrm{ed}\right.$, Sweet \& Maxwell, London, 2007) at 26; and A Ashworth, above $\mathrm{n} 17$, at 3 .

${ }^{36}$ A Ashworth, above $\mathrm{n} 17$, at 61.

${ }^{37}$ Easton and Piper, above n 4, at 20.

38 D Smith, H Blagg, and N Derricourt "Mediation in South Yorkshire" (1988), British Journal of Criminology Vol 28(3) 378.

${ }^{39}$ E Stockdale and K Devlin Sentencing $\left(1^{\text {st }}\right.$ ed, Waterlow Publishers, London, 1987) at 36.

${ }^{40}$ See Easton and Piper, above n 4, at ch 6.

${ }^{41}$ Sentencing Act, s 7.
} 
(b) to promote in the offender a sense of responsibility for, and an acknowledgment of, that harm; or

(c) to provide for the interests of the victim of the offence; or

(d) to provide reparation for harm done by the offending; or

(e) to denounce the conduct in which the offender was involved; or

(f) to deter the offender or other persons from committing the same or a similar offence; or

(g) to protect the community from the offender; or

(h) to assist in the offender's rehabilitation and reintegration; or

(i) a combination of 2 or more of the purposes in paragraphs (a) to (h).

These codify the traditional sentencing purposes, allowing judges the flexibility to determine the particular purpose of the sentence to be imposed. Of note in terms of reparation is subs (1)(b), (c) and (d) of s 7. A court may sentence an offender to provide for the interests of the victim under $s 7(1)(c)$. This should be read with $s 7(1)(b)$, promoting responsibility for harm. If an offender acknowledges the harm arising from the commission of the offence, this will often act as a mitigating factor to reduce the sentence. In a system based primarily on just deserts, as New Zealand arguably is, sentences will not be imposed merely in order to promote this sense of responsibility or to provide for the interest of victims. ${ }^{42}$ Just deserts refers to punishment relating to the offender's culpability and justified by retributivist principles. ${ }^{43}$ The interests of victims are relevant, but sentences should not be imposed based on satisfying the victim. ${ }^{44}$ The Court of Appeal determined that interpreting s 7(1)(c) as indicating that "heavy sentences should be imposed so the victims may, personally, feel vindicated" is the incorrect approach and "cannot have been the legislature's intent". 45 Subsections $7(1)(b)$ and $7(1)(c)$ are based on restorative justice principles, where the focus is on "the restoration of the victim, the community and the offender to their former position" by remedying the harm or loss that results from the offending. ${ }^{46}$

\footnotetext{
${ }^{42}$ B Robertson, above $\mathrm{n} 19$, at SA7.02.

${ }^{43}$ See Easton and Piper, above n 4, at 20, 23 and ch 2.5.

${ }^{44}$ B Robertson, above n 19, at SA7.02

${ }^{45} R$ v Tuiletefuga 25/09/2003, CA205/03 at [23].

${ }^{46}$ B Robertson, above n 19, at SA7.02.
} 
An exception to this comes in terms of the sentence of reparation, which is underpinned by the purpose under $\mathrm{s} 7(1)(\mathrm{d})$ of providing reparation for harm done. There is no explicit reference here to harm done to victims. Since the interests of victims are already provided for by $\mathrm{s} 7(1)(\mathrm{c})$, a reparation sentence might be intended to more generally provide reparation for harm done, in a way not limited to direct victims. This interpretation is based on a direct reading of the sentencing purposes. Despite this literal interpretation being possible, the courts have opted to read in the requirement of a victim for a reparation sentence, holding that the purpose of $\mathrm{s} 7(1)(\mathrm{d})$ provides only for reparation to the victims of offending. This determination, affirmed by the Supreme Court in Kapa, resulted in the reward donors being unable to receive reparation for the monetary loss they suffered as a result of Kapa's criminal offending.

\section{A Historical Development of Reparation}

Traditionally, the criminal law has not been formulated to be reparative or compensatory in nature. Crimes have been seen as "public wrongs against the community at large, resulting in punishment to express society's disapproval, to deter future offending, and to provide community protection". ${ }^{47}$ The theory of retributivism provides one digression from the traditional approach: it "links punishment according to the desert or culpability of the individual" and "matches the severity of the punishment to the seriousness of the crime". ${ }^{48}$ Reparation has also featured more generally within informal justice practices, whereby the community has sought to take disputes out of the formal legal process, away from adversarial procedures. ${ }^{49}$ The recent restorative justice 'movement' has seen reparation for harm become a primary concern with its focus on restoring harmony between the victim, offender and the community. ${ }^{50}$ In New Zealand, some possibility for compensation in the course of criminal proceedings was allowed through the compensation provisions in the Criminal Code Act 1893, and the Crimes Acts of 1908

\footnotetext{
${ }^{47}$ New Zealand Law Commission, above $\mathrm{n}$ 17, at [3.4].

${ }^{48}$ Easton and Piper, above $\mathrm{n}$ 4, at 8 and 55.

${ }^{49}$ See R Matthews Informal Justice? (Sage, London, 1988) at 99.

${ }^{50}$ Easton and Piper, above n 4, at 6.1.2.
} 
and $1961 .^{51}$ These were seen as compensation orders, separate to sentencing. The orders were little used, so compensation was afforded only in very limited circumstances. ${ }^{52}$

In recent years there has been a growing political need to recognise the victim's role within the criminal justice process. ${ }^{53}$ With a developing appreciation that "each criminal case involves more than the government versus the defendant. There is another party with a burning interest". 54 Accordingly, it can be reasoned that an important goal of both the criminal justice system and of sentencing ought to be justice to victims. ${ }^{55}$ The Declaration of Basic Principles of Justice for Victim and Abuse of Power furthered this victimfocused development on a global scale. ${ }^{56}$ This greater emphasis on the needs of victims and a subsequent focus on compensation from the 1980s paved the way for a growing number of restorative criminal justice schemes, whereby, amongst other functions, custodial sentences gave way to sentences to make reparation. ${ }^{57}$ The focus was taken away from the offender's fault; punishment was more clearly related to the harm to the victim, and centred on rendering justice to both victims and offenders. ${ }^{58}$ It must be noted that the approach of having too narrow a focus on victims has been criticised, ${ }^{59}$ and one response to the increased involvement of victims in the criminal justice process has been to recognise that "the victim's interest is part of the public interest but only part" ${ }^{60}$

\footnotetext{
${ }^{51}$ Criminal Code Act 1893, s 419; Crimes Act 1908, s 449; and Crimes Act 1961, s 403.

${ }^{52}$ Kapa $v$ R, above n 1, at [81]; Penal Policy Review Committee Report of the Penal Policy Committee (presented to the Minister of Justice, 1981) at [351].

${ }^{53}$ Easton and Piper, above n 4, at ch 6.4.1.

${ }^{54}$ R Davis, A Lurigio and W Skogan (eds) Victims of Crime $\left(2^{\text {nd }}\right.$ ed, Thousand Oaks, CA, Sage, 1997) at vii.

${ }^{55}$ A Ashworth Sentencing and Criminal Justice (2 ${ }^{\text {nd }}$ ed, Butterworths, London 1995) at 73.

56 Declaration of Basic Principles of Justice for Victims and Abuse of Power, United Nations (29 November 1985), Part A.

${ }^{57}$ Andrew Ashworth, above n 17, at 76; Easton and Piper, above n 4, at ch 6.3.1.

${ }^{58}$ B Smith and S Hillenbrand (1997) 'Making Victims Whole Again' in R Davis, A Lurigio and W Skogan (eds) (1997) Victims of Crime ( $2^{\text {nd }}$ ed, Thousand Oaks, CA, Sage) at 250.

${ }^{59}$ See Easton and Piper, above n 4, at ch 6.5.1.

${ }^{60}$ Andrew Ashworth (1993) 'Victim Impact Statements and Sentencing' Crimi LR, at 503.
} 
Reparation as a sentence was first introduced in the Criminal Justice Act. ${ }^{61}$ The provisions resulted from a recommendation that reparation ought to provide a regime to compensate for "all direct or indirect loss or damage suffered by any person as a result of the conduct giving rise to the proceedings in which the offender was convicted". ${ }^{62}$ The sentence was extended from property losses to cover emotional harm in $1987 .{ }^{63}$ It was advised that the courts "should lean towards making reparation orders in every appropriate case". ${ }^{64}$ A presumption in favour of reparation was enacted ${ }^{65}$ that was implemented by the courts ${ }^{66}$ and further reflected by the other related provisions. ${ }^{67}$ Reparation in the Criminal Justice Act could be broadly interpreted and imposed where the court was "satisfied that any act or omission that constituted the offence caused any loss of or damage to any property of another". ${ }^{68}$ This broad application was limited only by the statutory exclusion of "any loss or damage of a consequential nature" ${ }^{69}$ The current reparation sentence followed on from this provision. The sentence is intended to provide "a simple and speedy means of compensating those who suffer loss from criminal activities", ${ }^{70}$ averting the need to separately seek a civil remedy. The reparation sentence is enforced as if it were a fine. However, reparation is "compensatory in nature", 71 and "conceptually different from the punitive purpose of a fine". ${ }^{72}$ Reparation is intended to reinstate those who have suffered loss through criminal offending to their original position. $^{73}$

\footnotetext{
${ }^{61}$ Criminal Justice Act 1985, s 22.

${ }^{62}$ Penal Policy Review Committee, above n 52, at [351].

${ }^{63}$ Criminal Justice Amendment Act (No 3) 1987, s 4(1).

${ }^{64}$ Penal Policy Review Committee, above n 52, at [355].

${ }^{65}$ Criminal Justice Act, s 11.

${ }^{66} R v$ O'Rourke [1990] 1 NZLR 155 (CA) at 158.

${ }^{67}$ See Criminal Justice Act, s 22(7)-(8).

${ }^{68}$ Criminal Justice Act, s 22(1).

${ }^{69}$ Criminal Justice Act, s 22(5).

${ }^{70} R v O^{\prime}$ Rourke, above $\mathrm{n} 66$, at 158.

${ }^{71}$ Police v Ferrier 18/11/03 HC Auckland CRI-2003-404-195, at [15].

${ }^{72}$ B Robertson, above $\mathrm{n} 19$, at SA 32.04.

${ }^{73} R v$ Donaldson CA227/06, 2 October 2006 at [34].
} 
The suite of victims-rights based legislation that was enacted post-2000 further signalled recognition of the role of victims' interests in the criminal justice system. ${ }^{74}$ Collectively, $\underline{\text { the legislative changes suggested that a more restorative or reparative approach would be }}$ taken, with particular regard to the victims of crime. It must be noted that although these Acts often confer unenforceable rights, ${ }^{75}$ they do establish, to varying degrees, who ought to be considered as victims and grant these people some form of rights in recognition of their loss suffered. This legislative development initially appeared to allow greater recognition and rectification of harms that result from criminal offending. However, in strictly limiting eligibility for certain rights to direct victims, like the right to a reparation sentence, an arbitrary line has been drawn. Awarding reparation for harm resulting from criminal conduct is now based on whether or not the person at a loss fits the s 4 SA definition of 'victim'. The definition does not encompass all those who have suffered loss or harm as a result of criminal conduct, excluding from its ambit indirect victims of criminal offending. An unsatisfactory void has thus been created through this limitation to the sentence.

\section{B Reparation Case Law}

It is helpful to examine how reparation has been interpreted and applied from its inception to gain an understanding of its proper scope and how previous developments have led to the current application of the sentence. Since the sentence was introduced, ${ }^{76}$ reparation in terms of harm suffered in connection to an offence has been given a wide interpretation by the courts. That is, until the Supreme Court's decision in Kapa.

Tipping $\mathrm{J}$ in the High Court in Lovatt $v$ Police said that the sentence should be given a "liberal interpretation consistent with the spirit of reparation being ordered in all proper circumstances". ${ }^{77}$ The sentence requires the loss or damage to be suffered "through or by

\footnotetext{
${ }^{74}$ See Victims' Rights Act; Parole Act; Prisoners' and Victims' Claims Act; and Criminal Procedure Act.

${ }^{75}$ See Victims' Rights Act, s 10.

${ }^{76}$ Criminal Justice Act, s 22.

${ }^{77}$ Lovatt v Police HC Christchurch AP156/9, 2 August 1991.
} 
means of the offence". ${ }^{78}$ Tipping $\mathrm{J}$ held in Wilmot $v$ Police that it was sufficient that the conduct had "materially contributed" to the loss or damage. ${ }^{79}$ In Wilson v Police Gallen $\mathrm{J}$ determined that reparation could be ordered where a reasonable person could reasonably foresee the kind of harm or loss that occurred as a result of the offence. ${ }^{80}$ This requirement is to be interpreted in a broad, commonsense manner in light of the compensatory nature of reparation and "resort to refined causation arguments is not to be encouraged" in determining whether there is sufficient association between the loss and the offending. ${ }^{81}$ The English courts have taken a similar, non-technical approach to reparation. $^{82}$

The Court of Appeal in $R v$ Gill reluctantly held that the loss suffered was partly of a "consequential nature" to the offending, ${ }^{83}$ and the relevant s 22 provision did not allow for reparation to be ordered in those circumstances. ${ }^{84}$ The law has since been amended so that reparation for consequential loss or damage is now provided for under s $32(1)(\mathrm{c}) .{ }^{85} \mathrm{It}$ was argued by the Crown in Kapa that the reward donors suffered consequential loss for which reparation ought to be awarded. ${ }^{86}$ The court in $R v$ Ebdell held that the New Zealand Post (the Post) could recover its costs of restoring stolen property to the intended recipients as consequential loss. ${ }^{87}$ The majority in Kapa determined that this case was correctly decided but that it is distinguishable from Kapa on its facts, in that the Post's status differs from that of a reward donor. ${ }^{88}$ The Court based the distinction on ownership rights; the Post was the owner of the stolen property at the time of the theft, whereas the reward donors have no ownership title over the stolen medals. This indicates that a person with a legal or equitable interest in property who suffers consequential loss may be

\footnotetext{
${ }^{78}$ Sentencing Act, s 32(1).

${ }^{79}$ Wilmot v Police HC Dunedin AP25/96, 15 July 1996.

${ }^{80}$ Wilson v Police HC Napier, AP60/94, 13 February 1995.

${ }^{81} R v$ Donaldson, above $\mathrm{n} 73$, at [36].

${ }^{82}$ Bond $v$ Chief Constable of Kent [1983] 1 All ER 456 at 459.

${ }^{83} R v$ Gill (1992) 10 CRNZ 632 (CA) at 639.

${ }^{84}$ Criminal Justice Act, s 22(5).

${ }^{85}$ Sentencing Act, s32(1)(c).

${ }^{86}$ At [9].

${ }^{87} R v$ Ebdell [2009] NZCA 536.

${ }^{88}$ At [35].
} 
entitled to reparation, while someone with a mere "use" interest may not. On this analysis, since the reward donors had no ownership interest in the stolen medals, they could not be victims for reparation purposes.

The preceding broad interpretations of the reparation provisions culminated in the decision of Kapa with the Court taking a decidedly narrower approach to the application of the sentence. Despite Kapa receiving a pecuniary benefit from the offending at the burden of the reward donors, the majority determined that reparation is unavailable to benefit the reward donors. Only victims may recover for consequential loss or damage under s 32(1)(c), and reward donors cannot be classified as such. ${ }^{89}$ The reward donors remain deprived of the money, while Kapa is able to keep the $\$ 100,000$ as 'earnings' from the theft of the medals. The injustice in this outcome begs reconsideration of the appropriateness of limiting reparation to direct victims as defined by $\mathrm{s} 4$, and the question of whether the scope of the sentence should be extended.

In the light of this examination of reparation and its related elements, the sentence should not be restricted to a predetermined category of persons who are labelled the direct 'victims' of crimes. The sentence was developed as an efficient means to provide compensation for harms resulting from criminal offending. ${ }^{90}$ Compensation as part of criminal proceedings creates a fluid and cohesive scheme of recovery for those suffering loss or harm. Notwithstanding the recent legislative efforts to recognise victims' rights, in so limiting reparation, a considerable vacuum is created within this area of the law. Making reparation available only to direct victims takes away from the underlying broad compensatory aims of the sentence, and introduces difficulty in circumstances where a person has suffered through criminal activity but is not considered to be a victim under the s 4 definition. This way, the law is neglecting a group of people, who, despite having their interests violated by criminal offending, are left with no recourse to reparation by virtue of not fitting within the prescribed definition of 'victim'.

\footnotetext{
${ }^{89}$ Kapa $v$ R, above $\mathrm{n} 1$, at [15].

${ }^{90} R \vee O$ 'Rourke, above n 66, at 158.
} 
The Supreme Court's approach in Kapa, limiting compensatory rights to narrowly defined 'victims', overlooks the importance of mitigating the actual harm that results from the criminal offending. Those who have suffered loss or harm as a result of crime are not adequately compensated. Instead, the focus has narrowed so that only some people suffering loss in particular situations have recourse to rights and benefits as part of the criminal justice procedure. Although a limit is necessary, restricting eligibility for reparation to the particular definition of 'victim' confines the sentence too narrowly.

In the rest of this paper, it is argued that the current restriction on reparation is wrong for those cases where there is somebody who is not the direct victim of a charged offence, but who has suffered clearly manifested harm or loss because of the offending. The victim limitation renders the sentence of reparation deficient in giving effect to its purpose and an appropriate scope of application. Since the criminal behaviour has resulted in another's loss, the equilibrium should be restored by some mechanism, so that the burden of loss created by the offending is shifted back to the offender.

The issue arising from the Supreme Court decision in Kapa, where the person seeking compensation is not eligible for reparation by virtue of not being a 'victim', will only apply in a relatively small number of cases. Nonetheless, legal recognition and compensation for the harm suffered by this other group of people is certainly required. These indirect victims should not necessarily be afforded all the rights of the conventional victim, nor should those ordinarily charged with upholding victims' rights necessarily have the same extensive responsibilities for them. It is, however, argued that by virtue of being able to demonstrate loss suffered as a result of the offending, there should be some legal response so that compensation can be made available to this other group of people. The reward donors in Kapa suffered an identifiable loss associated with Kapa's criminal offending, and ought to be compensated for that loss through a reparation sentence. As reward donors, however, they cannot benefit from reparation, as they do not fit the required definition of victim. ${ }^{91}$ Although it may be unsurprising that the reward donors are not considered victims, they might "consider themselves as people

${ }^{91}$ Sentencing Act, s 4. 
who have lost money through or by means of the offending. That is in fact the inquiry to be made". ${ }^{92}$ The resulting injustice from this case should not go unnoticed, and should, in some way, be rectified.

Addressing this issue does not necessitate a vast extension of 'victim' or the adoption of an entirely new definition to encompass this other group of people; these options may be considered, but such a large-scale transformation might then impact too greatly on other areas of the law. Since the issue only affects a relatively small number of cases, it is appropriate to consider more measured changes to the reparation sentence, which will recognise the rights of these indirect victims with minimal impact on other criminal justice provisions.

\section{$V$ Suitability of the Criminal Law}

Before exploring any possibilities in terms of how to properly limit reparation while compensating indirect victims, another issue must be addressed. The concern is whether a reparation sentence at criminal law is the appropriate means to recognise and rectify the harm suffered by this other group of people. Other legal mechanisms, particularly within the civil jurisdiction, may be available to compensate this type of loss in many cases. Extending the criminal law in this area of sentencing may prove to be too large an impingement on individual rights, rendering the scope of the offender's responsibility unreasonably wide, especially in light of any other avenues for address that may be available. It is important to briefly consider alternative methods of redress, and, most importantly, to understand how they impact on possible developments of the current reparation provisions.

Civil law actions can compensate individuals, and could be available in place of a reparation sentence in some circumstances, depending on the particular facts of a case. Such actions include, but are in no way limited to, applications under the Criminal Proceeds (Recovery) Act 2009, or actions in tort or contract law.

${ }^{92}$ Kapa $v$ R, above n 1, at [116]. 
On the facts available within the existing judgments of Kapa, no assertion can be made that the reward donors have a civil claim either in tort or contract against Kapa for the reward money. The majority suggested that the reward donors might, however, have recourse to compensation as claimants in a civil law action. ${ }^{93}$ Although reparation is unavailable, Kapa could be stripped of the gain he received through a civil suit by means of the Criminal Proceeds (Recovery) Act 2009. Despite debate that such recovery is criminal in nature, ${ }^{94}$ the legislation establishes a civil law process to recover proceeds of criminal offences, separate to the criminal proceedings. ${ }^{95}$ Without a civil action being commenced, it remains uncertain whether this Act would serve to wholly compensate the reward donors in this case.

Despite the prospect of a civil claim being available to the reward donors, it is argued below that the criminal law can better address the loss suffered by the indirect victims. Through an analysis of the practical considerations, and by reference to the underlying nature and values of reparation as well as by analogy to other areas of the criminal justice process, the argument is reinforced that a reparation sentence is the more suitable mechanism to provide such relief.

First, from a practical standpoint, criminal procedure allows for an effective, cohesive, and streamlined process of recovery. Reparation serves as compensation, and is awarded at the conclusion of the state's action against the offender as part of the punishment for wrongdoing. This avoids the time-consuming and costly need for those burdened by criminal activity to independently pursue other avenues of compensation. Denying indirect victims the benefit of a reparation sentence forces those already disadvantaged to advance a case through the taxing civil law process, ${ }^{96}$ in the hope that it will result in some compensation for the initial damage suffered. This can be a heavy burden to

\footnotetext{
${ }^{93}$ At [38].

${ }^{94}$ See Liz Campbell "The Recovery of "Criminal" Assets in New Zealand, Ireland and England: Fighting Organised and Serious Crime in the Civil Realm" [2010] VUWLR, vol 41.

${ }^{95}$ Criminal Proceeds (Recovery) Act, ss 10, 15 and 16.

${ }^{96}$ See Kapa $v$ R, above $\mathrm{n} 1$, at [38].
} 
discharge, and the inherent risk of success carried with the civil claim may be restrictive in terms of whether or not an individual will eventually decide to pursue such a compensation claim. Denying a reparation sentence may also be prohibitive where compensation for a smaller amount is being sought. The possible cost of civil proceedings might outweigh the original loss, meaning that such proceedings may not be practicable, especially for those already disadvantaged by criminal conduct. Where there is a smaller claim for compensation, there may be other avenues to provide the relief sought. Such mechanisms might include, for example, action involving disputes tribunals or redress through alternative dispute resolution techniques. ${ }^{97}$ The claimant must still pass any hurdles required by the particular mechanism, and may ultimately find that he or she cannot fit the criteria to bring the claim, or that there is some other barrier to bringing the claim. This is in contrast to the reparation sentence, where the offender has been convicted of the crime and compensation through reparation may be considered alongside other punishments as part of the overall sentencing process.

Additionally, extending reparation to include indirect victims is consistent with the core values that underlie sentencing and the particular aims of the sentence, as distinct from the core principles of criminal conviction. The relevant considerations here include the compensatory nature of reparation, its role as a loss-shifting mechanism and its judiciallysanctioned wide and liberal interpretation. Such extension would ensure recognition of the rights of those suffering loss or harm through criminal conduct, and would mitigate this harm to the greatest extent possible.

Lastly, the criminal law already recognises the rights and interests of third parties in some areas. These interested parties are not considered 'victims' of criminal offending; nor are they the offender, a claimant, or a party to the legal action. The criminal law has made such provision notably in the area of disclosure requirements and evidential rules. Under the Criminal Disclosure Act 2008 for example, the defendant can make an application for non-party disclosure, which extends disclosure obligations to material held by an

\footnotetext{
${ }^{97}$ See generally R Matthews Informal Justice?, above n 49; and Easton and Piper, above n 4, at ch 6.
} 
independent third party. ${ }^{98}$ With such provisions in mind, a better evaluation of reparation can be made. The reparation sentence could accordingly be extended so that third-party rights and interests can be similarly addressed in these questions of compensation.

Modifying the existing reparation sentence is the better way to ensure that all loss associated with criminal behaviour is appropriately mitigated. Any alternatives would see compensation within the criminal law remaining unavailable to this other group of indirect victims, so that those suffering loss need to pursue other, more taxing, actions in the hope of redress.

\section{Possible Limits to Reparation}

Having determined that the criminal law ought to be the mechanism to address the interests of these indirect victims, the question then becomes where the line should be drawn in providing legal recognition and the right to compensation. If the current definition of victim inappropriately limits reparation, another way of establishing who ought to be able to benefit from the sentence must be devised. The law cannot allow compensation for harms to an endless number of people or indefinite section of society.

Alternative limitations can be formulated by changing who is considered to be a victim: either by extending the current definition, creating a particular definition for reparation purposes, or by leaving open who may be considered a victim so that it is determined in the specific circumstances. A contentious alternative could be to remove the requirement to have a victim for reparation entirely. A new threshold to limit reparation might then be introduced; the threshold could be based on the harm that results from the offending, based on the culpability of the offender, or it could be a specific requirement fixed on the remoteness of the loss or harm. These options are considered in the following paragraphs. A Changing the Definition of 'Victim'

\footnotetext{
${ }^{98}$ Criminal Disclosure Act 2008, s 24(5).
} 
The s 4 definition of victim could be extended to include a much wider range of people, so that anyone disadvantaged by an offence is considered a victim. The reward donors would then be eligible to receive reparation for their pecuniary loss. Similar wording to define the scope of 'victim' can be found in the VRA. ${ }^{99}$ An amendment to broaden the definition of "victim" had previously been suggested to specifically include every "complainant in relation to an offence". ${ }^{100}$ This definition was, however, replaced by the narrower "person against whom an offence is committed". ${ }^{101}$ Extending the definition of victim for all purposes might be objectionable, since it may have broad implications affecting other provisions of the SA that rely on this definition. For example, certain aggravating and mitigating factors for sentencing take into account the rights, interests and status of the 'victim'. ${ }^{102}$ If a broader approach to the term 'victim' is taken, there may be a direct impact on the actual imposition of other sentences beyond reparation; for example, if the extended definition is used for consideration of the s 9 factors. ${ }^{103}$ Such an extension may have too negative an effect if we consider that other provisions, which rely on the definition of victim, may be more appropriately executed with the current, narrower definition.

Otherwise, a definition of victim may be devised specifically for the sentence of reparation. This would be broader than the s 4 definition and include anyone associated with the criminal offending who suffers some loss. Having a specific definition of victim for a particular purpose is not unparalleled. Such an approach would be comparable to the VRA, with its varied applications of the term 'victim'. ${ }^{104}$ The current definition could be retained with a supplementary definition provided for reparation. For example, following the current 'victim' definition, the provision might read: "In addition, for the purposes of s 32, any person who has suffered loss or damage that is in some way related to the criminal offending may be considered a victim." Such a contained extension may be the

\footnotetext{
${ }^{99}$ Victims' Rights Act, s 20.

${ }^{100}$ Sentencing and Parole Reform Bill 2001 (148-2), cl 4(a)(i) in relation to the definition of "victim".

${ }^{101}$ Sentencing Bill 2001 (148-3A), cl 4.

${ }^{102}$ Sentencing Act, $\mathrm{s} 9$.

${ }^{103}$ See Sentencing Act, s 9(1)(f),(fa),(fb),(g),(h)(ii) and s 9(2)(c).

${ }^{104}$ See Victims' Rights Act, ss 4, 7, 8 and 20.
} 
most suitable way to address the issue; it would ensure that reward donors were eligible to benefit, but it would not be too far-reaching so as to impact directly on other provisions that require consideration of the term 'victim'.

The definition of victim could also be left open, and utmost discretion allowed as part of the sentencing process to determine whether a person suffering loss has been victimised for reparation purposes. Similarly, the VRA currently grants the prosecutor discretion to determine whether a person is a victim for the purposes of victim impact statements. ${ }^{105}$ This flexible approach avoids pre-determining who a victim can be, so there is scope to recognise those who should have their interests protected in the particular circumstances. Provision of this sort for reparation may be contentious due to the wide discretion it would confer, the lack of certainty it could create, and the opportunity for inconsistencies to develop in its application. The discretion granted could be widely and liberally exercised, so appropriate restrictions on this power would need to be place. For example, those sanctioned to make this determination should be limited to certain persons with a degree of expertise and some mandatory considerations should also be included to guide the determination of whether a particular person is a victim; such guidelines could be derived from the sentencing principles earlier identified. The line might otherwise become blurred between allowing judicial discretion to find a just outcome in certain fact scenarios and allowing free exercise of discretion so that judicial decisions are based upon broad policy determinations that ought to be left to Parliament. The rule of law involves judicial decisions being taken openly and by reference to standards declared in advance. ${ }^{106}$ The inherent lack of certainty created by leaving the definition of 'victim' open could be problematic in upholding this legal standard, and could lead to an inconsistent application of the law. However, with an accumulation of case law, some established standards to apply when determining who is a victim could be broadly delineated. Although it might be deemed radical, this change would likely result in a higher number of just outcomes in the application of reparation as a sentence.

\footnotetext{
${ }^{105}$ Victims' Rights Act, s 20.

${ }^{106}$ A Ashworth, above n 17, at 62; and see J Raz The Authority of Law: Essays on Law and Morality (Oxford University Press, Oxford, 1979) at ch 11.
} 
Determining who is a victim could be more fairly and flexibly assessed, so that eligibility for reparation could truly be ascertained on a case-by-case basis.

\section{B Removing the Requirement of 'Victim'}

A more preferable route to ensuring the compensation of those who suffer harm may be to stipulate that an award of reparation should depend on the harm done, directly or consequentially on the offence, rather than on whether the person harmed is a "victim". An analysis of the harm or loss suffered could directly inform who can be considered a beneficiary of reparation. Rather than limiting the sentence to benefit a certain category of person, as it is currently restricted to direct victims, it might be available to any person who has suffered any sort of identifiable harm associated with the criminal offending. The aforementioned discretionary approach involved an analysis of the particular facts with a view to determining who can be labelled a 'victim' and therefore eligible for reparation. This approach, by contrast, removes the victim requirement entirely and establishes that if a person or persons can show an identifiable or measurable harm or loss, they ought to be compensated in law. In the majority of cases, a pecuniary loss could be relatively straightforward to manifest. For example, the reward donors in Kapa can point to the $\$ 100,000$ that they put up as a reward, which ended up being paid to Kapa, as the loss they incurred. Having to show the harm or loss could prove more burdensome when a person seeks reparation for harm that is not pecuniary. For example, if reparation for emotional harm is sought. Although less straightforward to manifest, this requirement would not necessarily bar such a claim for compensation. Demonstration of the harm or loss suffered could therefore be introduced as the standard to ensure that reparation is available to the appropriate range of persons.

Alternatively, the sentence of reparation could be dependent on the culpability of the convicted offender. When the offender has subjectively foreseen or even intended the loss or harm actually suffered, reparation for that anticipated loss could be appropriate. A reparation sentence would depend on the offender's actual or objective culpability, and it would be unnecessary to categorise the person suffering harm as a 'victim'. Whether the 
assessment is to be of subjective or objective culpability may depend on the circumstances of the case. Kapa and his accomplice did in fact foresee the receipt either of some pecuniary benefit or a negotiation of other charges for offending as a result of the burglary. ${ }^{107}$ Receiving a reward was partly the reason for the burglary, and Kapa admitted the intention to ask "for a ransom" for the medals. ${ }^{108}$ Under this culpability-based limitation, it would be said that the dominant motivation there for the offending was the loss actually suffered by the reward donors, so reparation should be available.

Recourse to particular remoteness or causation formulations is discouraged under the traditional approach to reparation. Rather, the viewpoint adopted is that the sentence should be approached in a broad commonsense way, to give full effect to its compensatory nature. ${ }^{109}$ However, the 'victim' limitation could be dispensed with and replaced by an investigation centred on remoteness of the harm. Instead of an analysis based on the person suffering loss, the primary consideration would be the harm or loss that is directly linked to the offender. Whether reparation is available would depend on whether there is a sufficient direct link between the offender and the harm or loss suffered, taking into account common law principles of causation. ${ }^{110}$ In Kapa, the loss of the donors' reward money is directly linked to Kapa. The burglary prompted the medals agreement, where the reward donors paid the $\$ 100,000$ to Kapa, overall, resulting in a direct gain for Kapa at the disadvantage of the reward donors. There is no act to break the chain of causation between Kapa's burglary and the reward donor's payment.

This exploration of alternative limits on reparation is useful to identify how the current sentence could be advanced, so that indirect victims also receive compensation in the appropriate circumstances. The six alternative limits to reparation proposed above would each address this issue and establish a more suitable scope for the sentence.

\footnotetext{
107 At [47].

${ }^{108} R v$ Kapa, above $\mathrm{n} 10$, at [7] (sentencing notes).

${ }^{109} R v$ Donaldson, above $\mathrm{n} 73$, at [30]-[35].

${ }^{110} R v$ Donaldson, above $\mathrm{n} 73$, at [36].
} 


\section{Conclusion}

Since a legislative amendment to the existing reparation provisions is appropriate to address compensation for indirect victims, the best approach is one with minimal impact on other areas of the law, considering the issue to be addressed will only be present in a relatively small number of cases. Accordingly, the best method would be the second adaptation to the 'victim' requirement outlined above. This involves introducing an additional provision that allows for a wider definition of 'victim' to be used for the purposes of s 32. The wider supplementary definition would include indirect victims, but would be limited in application to the specified reparation provisions. The current 'victim' definition could otherwise remain unaltered. Such a change is consistent with the overall compensatory nature of reparation. It is not, however, a radical advancement that would make reparation available to too large a category of claimants, or have any unnecessary impact on other areas of the law.

In the case of Kapa, with such a provision, the reward donors would be eligible to receive reparation from Kapa for the $\$ 100,000$ reward payment, as they suffered loss resulting from Kapa's crime. This would serve to restore the imbalance created by Kapa's criminal offending. The restoration would occur inherently as part of the criminal justice process and no further action outside of this would be required ensure that the reward donors were availed of their loss. Such legislative change to reparation would therefore lead to what is irrefutably the most just outcome in this case, and allow for reparation to be considered in any other similarly appropriate cases. 


\section{Bibliography}

\section{A Cases \\ $1 \quad$ New Zealand}

Attorney-General v District Court at Otahuhu (2001) 19 CRNZ 29 (CA).

Kapa $v$ R [2012] NZSC 1.

Lovatt v Police HC Christchurch AP156/9, 2 August 1991.

Police v Ferrier HC Auckland CRI-2003-404-195, 18/11/03.

$R v$ Donaldson CA227/06, 2 October 2006.

$R v$ Gill (1992) 10 CRNZ 632 (CA).

$R v$ Kapa [2011] NZCA 504.

$R v$ Kapa DC Auckland CRI-2008-083-2487, 26 August 2010.

$R v$ Ebdell [2009] NZCA 536.

$R v$ O’Rourke [1990] 1 NZLR 155 (CA).

$R v$ Rollo [1981[ 2 NZLR 667 (CA).

$R v$ Tuiletufuga CA 205/03 25 September 2003.

Stirling v Police HC Invercargill CRI-2003-425-18, 22 December 2003.

Wilmot v Police HC Dunedin AP25/96, 15 July 1996.

Wilson v Police HC Napier AP60/94 13 February 1995.

2 United Kingdom

Bond v Chief Constanble of Kent [1983] 1 All ER 456.

\section{B Legislation}

Crimes Act 1908.

Crimes Act 1961.

Criminal Code Act 1893.

Criminal Disclosure Act 2008.

Criminal Justice Act 1985.

Criminal Justice Amendment Act (No 3) 1987.

Criminal Procedure Act 2011.

Criminal Proceeds (Recovery) Act 2009. 
Evidence Act 2006.

Parole Act 2002.

Prisoner and Victim' Claims Act 2005.

Sentencing Act 2002.

Victims’ Rights Act 2002.

\section{Treaties}

Declaration of Basic Principles of Justice for Victims and Abuse of Power, United Nations (29 November 1985).

\section{Books and Chapters in Books}

A Ashworth Principles of Criminal Law (4 ${ }^{\text {th }}$ ed, Oxford University Press, Oxford, 2003). A Ashworth Sentencing and Criminal Justice ( $2^{\text {nd }}$ ed, Butterworths, London, 1995). A Ashworth Sentencing and Criminal Justice ( $3^{\text {rd }}$ ed, Butterworths, London, 2000). A Ashworth Sentencing and Penal Policy (Weidenfeld and Nicolson, London, 1983). A Ashworth The Criminal Process: An Evaluative Study (Clarendon Press, Oxford, 1994).

A Ashworth and M Wasik (eds) Fundamentals of Sentencing Theory (Clarendon Press, Oxford, 1998).

CK Boyle and MJ Allen Sentencing Law and Practice (Sweet \& Maxwell, London, 1985).

CMV Clarkson, HM Keating and SR Cunningham Clarkson and Keating Criminal Law: Text and Materials ( $6^{\text {th }}$ ed, Sweet \& Maxwell, London, 2007).

R Davis, A Lurigio and W Skogan (eds) Victims of Crime $\left(2^{\text {nd }}\right.$ ed, Thousand Oaks, CA, Sage, 1997).

RA Duff Answering for Crime: Responsibility and Liability in the Criminal Law (Hart, Oxford, 2007).

S Easton and C Piper Sentencing and Punishment: The Quest for Justice $\left(2^{\text {nd }}\right.$ ed, Oxford University Press, Oxford 2008). 
J Feinberg 'The Expressive Function of Punishment' in A Duff and D Garland (eds) $A$ Reader on Punishment (Oxford University Press, Oxford, 1994).G Hall Hall's Sentencing (Butterworths, Wellington, 1993).

R Matthews Informal Justice? (Sage, London, 1988).

D Ormerod Smith and Hogan's Criminal Law $\left(13^{\text {th }}\right.$ ed, Oxford University Press, Oxford, 2011).

T Milligan and MS Williams The Proceeds of Crime - Law and Practice of Restraint, Confiscation, Condemnation and Forfeiture $\left(2^{\text {nd }}\right.$ ed, Oxford University Press, Oxford, 2007).

L Radzinowicz The Profits of Crime and Their Recovery: The Report of a Committee Chaired by Sir Derek Hodgson (Heinemann, London 1984).

J Raz The Authority of Law: Essays on Law and Morailty (Oxford University Press, Oxford, 1979).

AP Simester and WJ Brookbanks Principles of Criminal Law (Brookers, Wellington, 2012).

AP Simester and others Criminal Law: Theory and Doctrine $\left(4^{\text {th }}\right.$ ed, Hart, Oxford, 2010).

B Smith and S Hillenbrand 'Making Victims Whole Again' in R Davis, A Lurigio and W Skogan (eds) Victims of Crime ( $2^{\text {nd }}$ ed, Thousand Oaks, CA, Sage, 1997).

E Stockdale and K Devlin Sentencing ( $1^{\text {st }}$ ed, London, Waterlow Publishers, 1987).

A von Hirsch and A Ashworth Proportionate Sentencing: Exploring the Principles

(Oxford University Press, Oxford, 2005).

A von Hirsch, A Ashworth and J Roberts Principled Sentencing: Readings on Theory and Policy ( $2^{\text {nd }}$ ed, Hart, Oxford, 2009).

A von Hirsch Censure and Sanctions (Oxford University Press, New York, 1993).

N Walker Sentencing: Theory, Law and Practice (Butterworths, London, 1985).

\section{E Looseleaf Texts}

Sir Bruce Robertson Adams on Criminal Law - Sentencing (online looseleaf ed, Brookers).

\section{F Journal Articles}


D Smith, H Blagg, and N Derricourt "Mediation in South Yorkshire” (1988) 28(3) BJC 378.

DA Thomas "Sentencing: The Basic Principles" [1967] Crim LR 455.

Liz Campbell "The Recovery of "Criminal” Assets in New Zealand, Ireland and England: Fighting Organised and Serious Crime in the Civil Realm” [2010] 41 VUWLR.

\section{G Parliamentary and Government Materials}

Sentencing and Parole Reform Bill 2001 (148-2).

Sentencing Bill 2001 (148-3A).

Supplementary Order Paper 2002 (262) Sentencing and Parole Reform Bill 2001 (148-2) (explanatory note).

Victims of Crime Reform Bill 2011 (319-2).

\section{H Reports}

Criminal Justice Policy Group Review of Monetary Penalties in New Zealand (Ministry of Justice, June 2000).

Ministry of Justice Sentencing Policy and Guidance - A Discussion Paper (Ministry of Justice, Wellington, November 1997).

New Zealand Law Commission Compensating Crime Victims (NZLC IP11, 2008).

New Zealand Law Commission Compensating Crime Victims (NZLC R121, 2010).

Judy Paulin, Wendy Searle and Trish Knaggs Attitudes to Crime and Punishment: A New Zealand Study (Ministry of Justice, December 2003).

Penal Policy Review Committee Report of the Penal Policy Committee (Presented to the Minister of Justice, 1981). 


\section{Word count}

The text of this paper (excluding table of contents, abstract, footnotes, and bibliography) comprises approximately 7996 words. 